Arch. histol. jap., Vol. 42, No. 5 (1979)

p. $551-561$

\title{
Electron Microscope Study on the Contact of Neural Crest Cells in the Early Stage of Migration in Bantam Embryos
}

\author{
Hitoshi TAKahashi and Takashi YAMAdori \\ Department of Anatomy (Prof. T. YAmadori), Hirosaki University School of Medicine, \\ Hirosaki, Japan
}

Received March 9, 1979

\begin{abstract}
Summary. The early stage of migration of neural crest cells was observed in the midbrain level of bantam embryos (5-somite stage to 15 -somite stage) by transmission electron microscopy. It was confirmed that the migration of the neural crest cells starts at the stage of 7-8 somites and ends at the stage of about 14 somites. During this period, not only the contact of migrating crest cells with each other but also the contact between migrating cells and superficial ectodermal cells and/or neural tube cells was observed. Intercellular distance in those contact regions was $3-4 \mathrm{~nm}$. The contact between the migrating crest cell and the basement membrane of the neural tube cell and of the ectodermal cell as well as the contact between the neural crest cell and the fibrillar structure in the environment was also seen. These findings suggest the possibility of transitory interaction for migration between neural crest cells with each other, between neural crest cells and cellular components of the environment where these crest cells migrate, and between neural crest cells and extracellular structures in the environment.
\end{abstract}

Recently the importance of cell interaction during tissue differentiation and morphogenesis has come to be recognized. In 1972 WESTON reported that there is, at least in the case of neurons and pigment cells, a general correlation between the spatial arrangement of crest cells and their phenotypic expression, because neuronal differentiation is normally manifest only when crest cells interact closely in cohesive clusters, and melanogenesis proceeds, on the contrary, when crest cells are initially dispersed. He also stated that the neural crest has special attributes as a system to investigate the role of cell interaction in the control of morphogenetic movements, the formation of specific cell contacts, and the regulation of cellular phenotypic expression. JoHnston and Listgarten (1972) supposed that during their migration the cranial neural crest cells become associated with various types of tissues from which they appear to receive inductive stimuli for migration and differentiation. NoDEN (1975) also indicated that the migratory behavior of neural crest cells is largely directed by environmental influences. Therefore, the authors intended to study the cell contact in the early stages of the neural crest cell migration in the midbrain level by electron microscopy, namely, how closely neural crest cells approach neural tube cells or superficial ectodermal cells which are the main components of the 


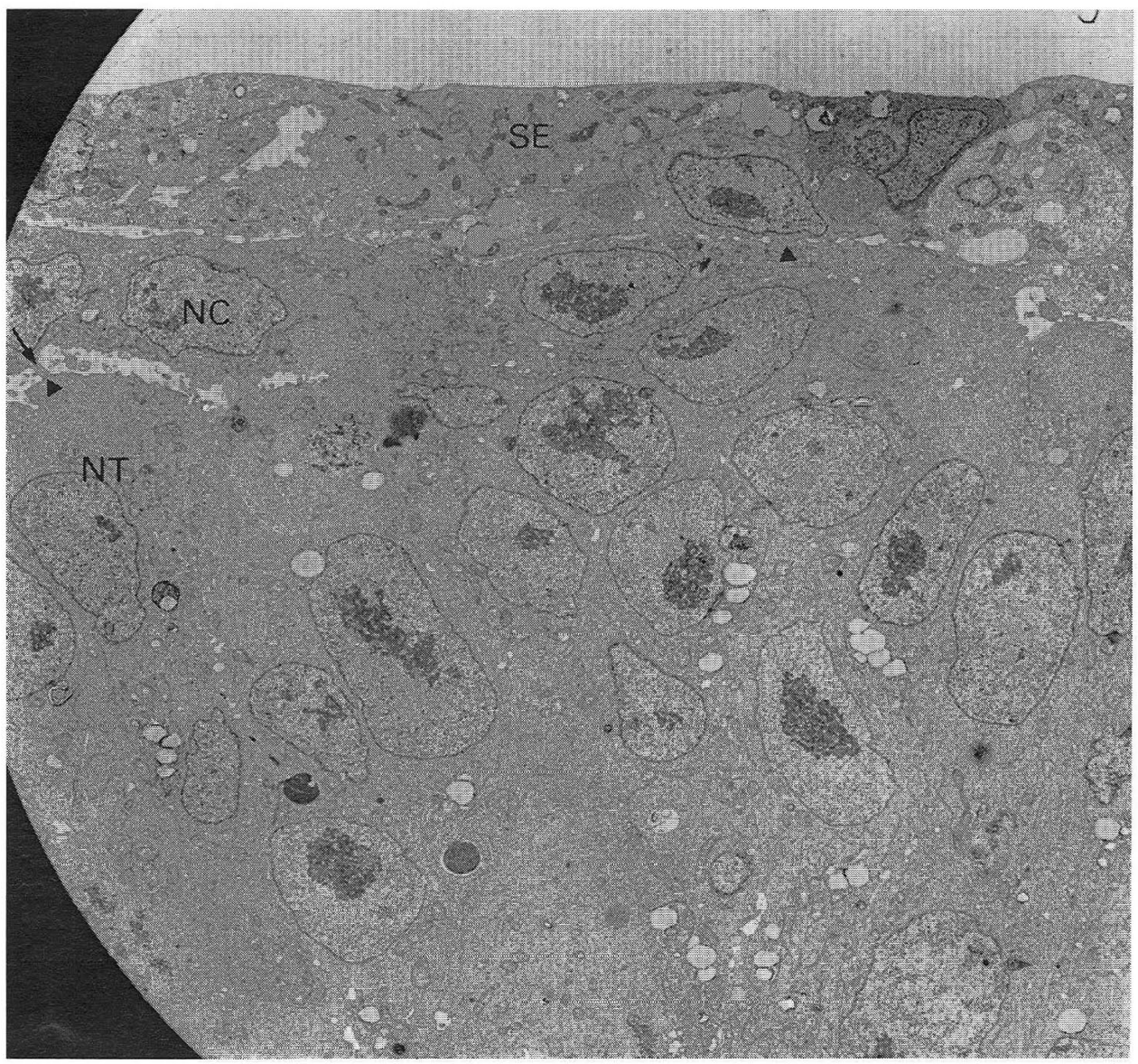

Fig. 1. Electron micrograph showing the mid-dorsal portion of a neural tube in the bantam embryo of 9-somite stage. The mass of migrating neural crest cells (NC) appears as a strand because these cells associate closely with each other. This mass is also in contact with superficial ectodermal cells (SE) and neural tube cells (NT) (arrow-head and arrow). The portions indicated by an arrow-head and an arrow are magnified in Figures 2 and 3. $\times 2,400$

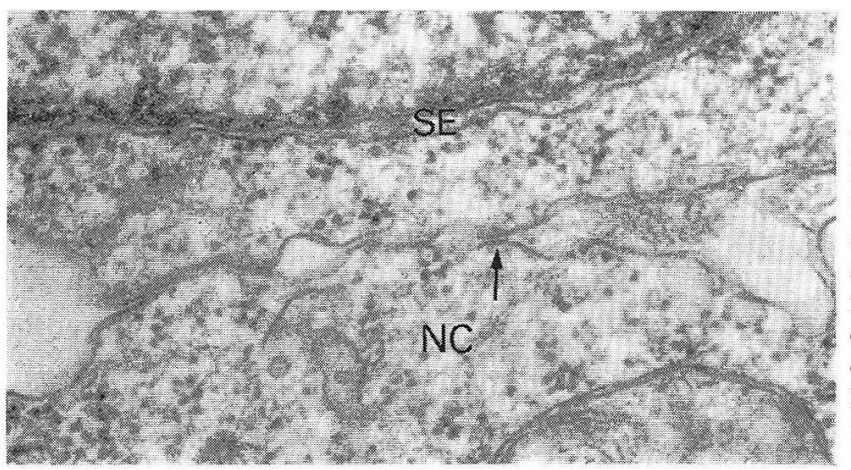

Fig. 2. Electron micrograph of higher magnification showing the portion indicated by the arrow-head in Figure 1. An arrow points to the contacting region between the neural crest cell $(N C)$ and the superficial ectodermal cell (SE). The intercellular width is about $3 \mathrm{~nm}$. $\times 50,000$ 
embryonic environment in this stage of development. At the same time the authors intended to investigate the varieties of contact of migrating neural crest cells which would be observable by electron microscopy.

\section{MATERIALS AND METHODS}

Japanese bantam embryos (Gallus gallus domesticus Brisson) from the 5-somite stage to the 15-somite stage were used in the present study. Desirable stages of embryos were obtained by incubating fertile bantam eggs for a certain period (cf. HAMBURGER and HAMILTON, 1951) at $38-38.5^{\circ} \mathrm{C}$. The fore- and midbrains were taken out by cutting the embryo at the anterior part of the hindbrain with a razor blade and the specimen was fixed for $60 \mathrm{~min}$ in a cold mixture of $0.1 \mathrm{M}$ sodium cacodylate buffered ( $\mathrm{pH} 7.4$ ) $2 \%$ glutaraldehyde and 4\% acrolein (SAIto and KeIno, 1976). Then, the specimen was washed for 30 to 40 min with the buffer solution and postfixed with a $2 \%$ osmium tetroxide solution (Millonig, 1962) for $60 \mathrm{~min}$. The specimen was washed again for 30-40 min by the same buffer and stained en bloc with $1 \%$ uranyl acetate for $60 \mathrm{~min}$ at room temperature (modification of the method of KELLENBERGER et al., 1958). The fixed specimen was embedded in Epoxy resin (LUFT, 1961), after rapid dehydration in the usual series of ethanol. Ultrathin sections were prepared at the midbrain level and were stained with uranyl acetate and the lead solution of SATo (1967). A Hitachi HU 12 AS electron microscope was used for the observation. For orientation to the electron microscope observation, thicker sections of about $1 \mu \mathrm{m}$ thickness were also prepared and observed by light microscope after being stained with $0.5 \%$ toluidine blue.

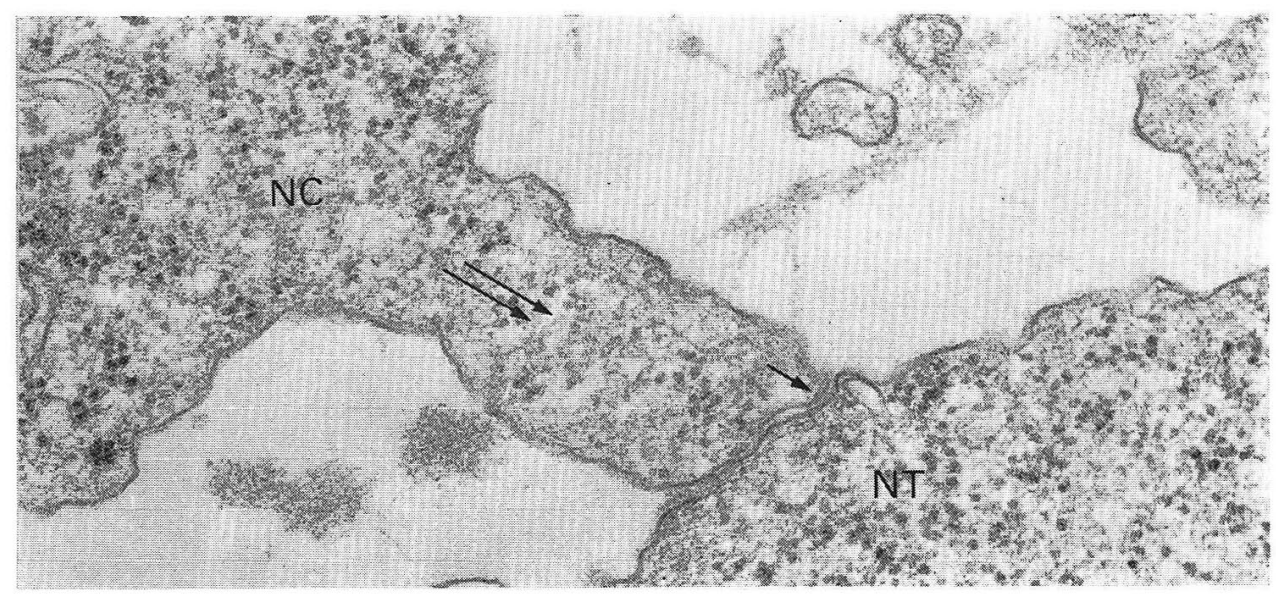

Fig. 3. Electron micrograph of higher magnification showing the portion indicated by the arrow in Figure 1. A pseudopodium (double arrows) is protruded from the crest cell (NC) and reaches close to the neural tube cell $(N T)$. An arrow shows the contacting region between the pseudopodium and the neural tube cell. The width of the intercellular space is about $4 \mathrm{~nm}$. The contact between the pseudopodium of the neural crest cell and the fibrillar structure in the intercellular space is also observable. $\times 52,000$ 


\section{OBSERVATION}

Electron microscope observation of bantam embryos confirms that neural crest cells in the midbrain level start to leave their source at the stage of 7 or 8 somites. The crest cells seem to be briskly pushed out or to creep out themselves from the source continuously and divide themselves into two strands in bilateral directions (Fig. 1). A photograph of the midbrain level in the 12-somite stage shows that the exodus of the cell from the source is coming to an end as the escaping crest cells seem to

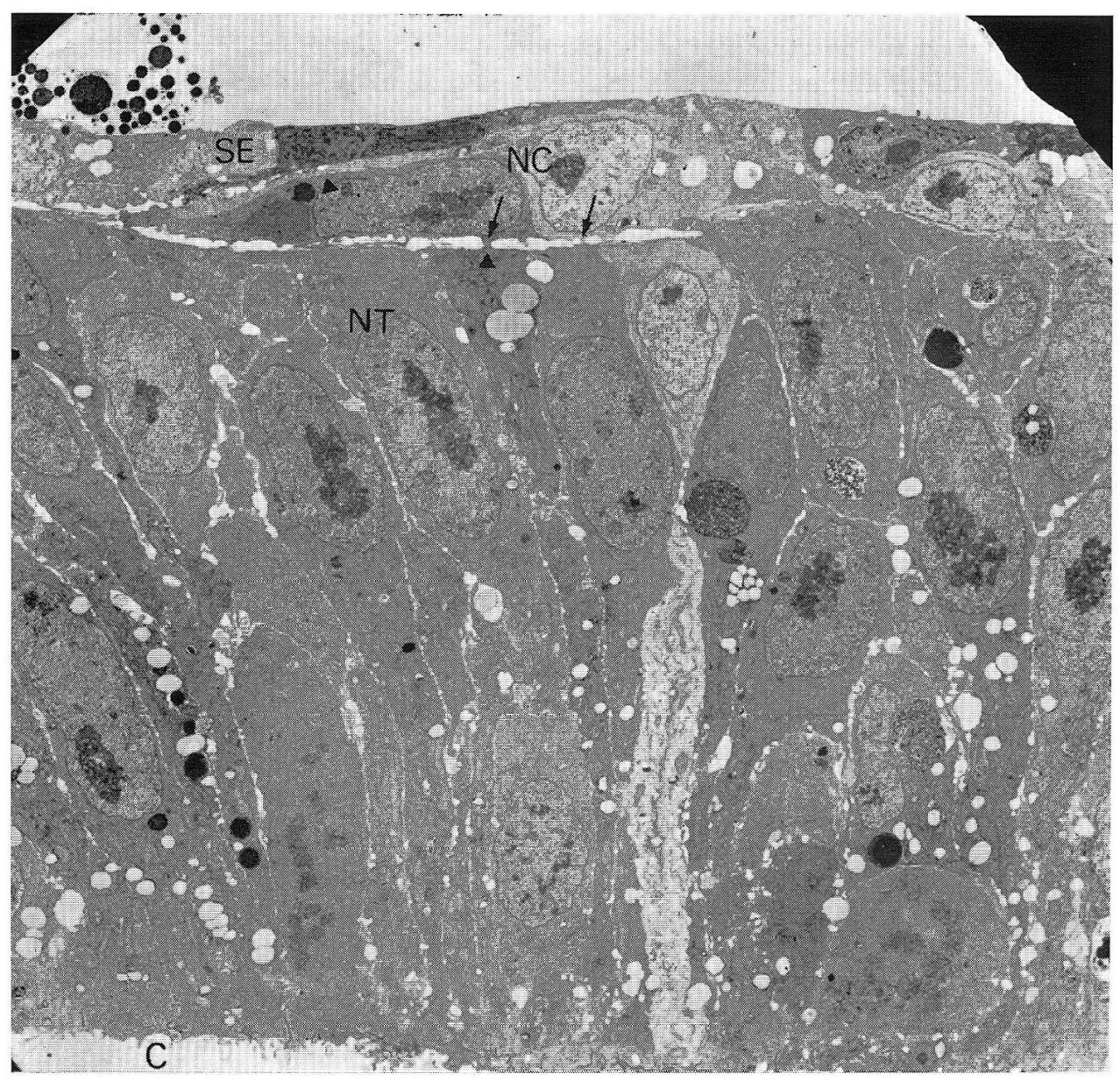

Fig. 4. Electron micrograph showing the mid-dorsal portion of a neural tube in the bantam embryo of 12 -somite stage. Crest cells $(N C)$ are decreased in number and seem to migrate toward the left side of the micrograph within the space between the ectoderm $(S E)$ and the neural tube $(N T)$. During migration, the crest cells are in tight contact with the broad area of the cell membrane of the ectoderm and also in contact with the neural tube by protruding pseudopodia (arrows). In the left-lower part of the micrograph the neurocoel $(C)$ is observable. The portions indicated by arrow-heads are magnified in Figures 5 and $6 . \times 2,400$ 
decrease (Fig. 4). At the 13-somite stage the complete closure of the neural tube, namely, the separation of the neural tube from the superficial ectoderm is seen in many examined sections. Figure 7 shows the stage just before the complete closure of the neural tube. Even in this stage, a few crest cells, which are just under the superficial ectoderm and thought to be rear positioning migrating cells, are still seen. These cells are observable until the 15-somite stage.

It is noted that the neural crest cells which are migrating in the dorsal part of the neural tube are in contact not only with each other but also with superficial ectodermal cells and/or neural tube cells (Fig. 1, 4, 7). The contacts are superabundant on the dorsal part of the neural tube, and are frequently observable even at the areas of two and ten o'clock of the neural tube. With the ectodermal cells, the

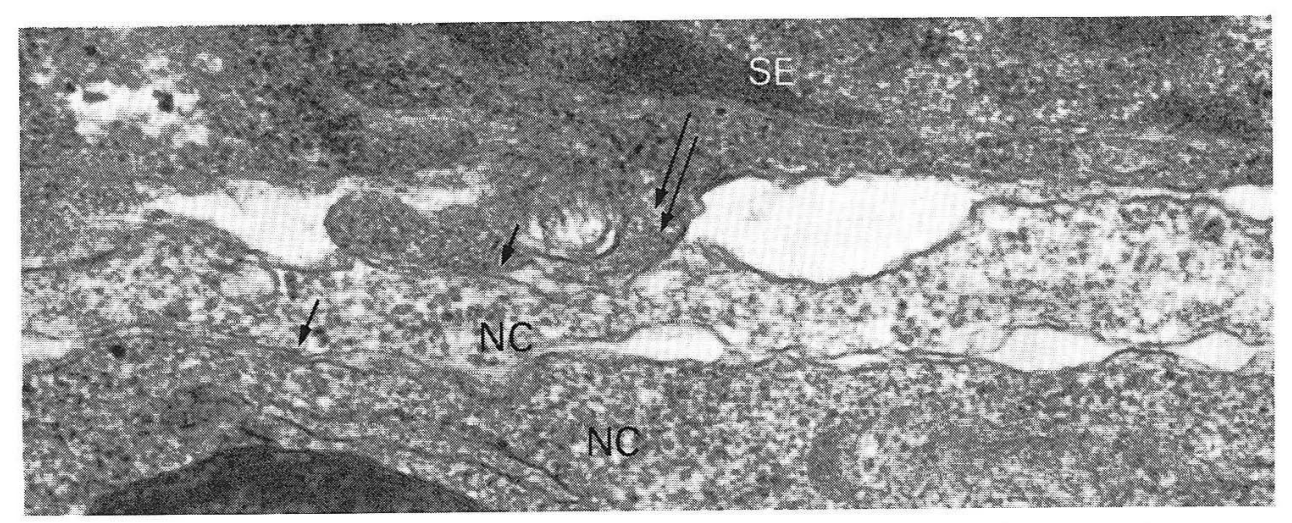

Fig. 5. Elactron micrograph of higher magnification showing the portion indicated by the arrowhead in the left upper part of Figure 4. A pseudopodium (double arrows) which protrudes from the ectodermal cell (SE) toward the crest cell $(N C)$ is observed. Arrows point to contacting regions between the pseudopodium and the crest cell as well as between two crest cells. $\times 50,900$

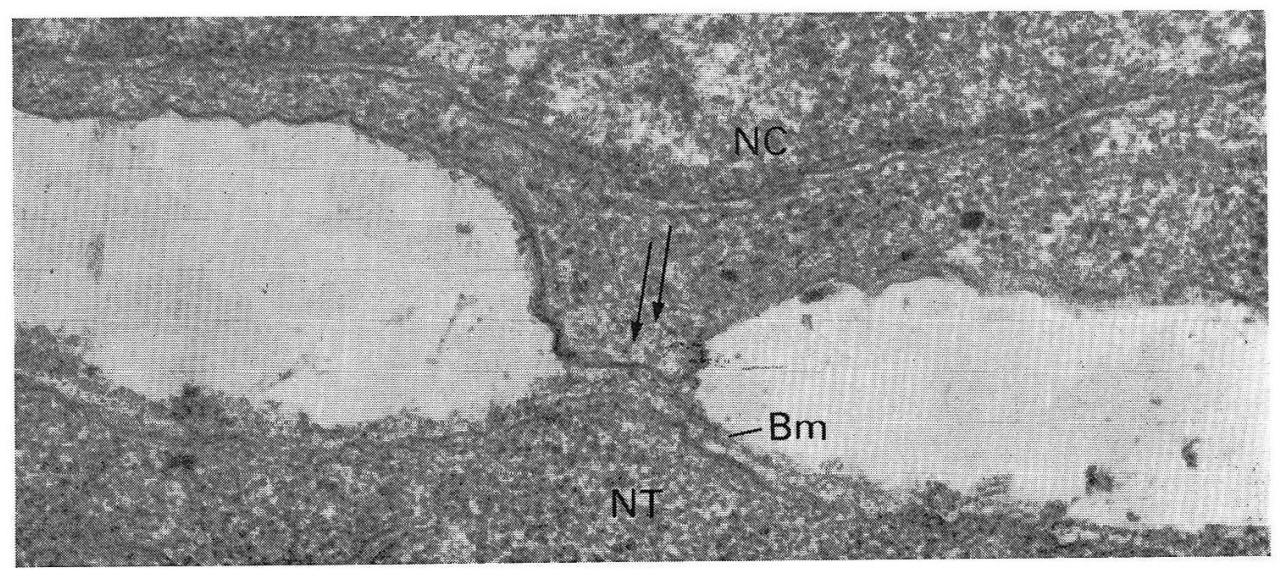

Fig. 6. Electron micrograph of higher magnification showing the portion indicated by the arrow head in the upper-middle part of Figure 4 . The crest cell $(N C)$ is in contact with the basement membrane $(B m)$ of the neural tube cell $(N T)$ by protruding a pseudopodium (double arrows). $\times 49,000$ 
neural crest cells make contact by protruding either some small pseudopodia or many minute processes. In the latter case the cell body of the neural crest cell approaches the ectodermal cell up to a distance of $7-10 \mathrm{~nm}$ but no further. However, many minute processes which are protruded from the cell body approach the ectodermal cell to a distance of $3 \mathrm{~nm}$ or even closer (Fig. 2, 9, 10). A conversed relation, namely, the ectodermal cell protruding its pseudopodia to the crest cell, is also seen frequently (Fig. 5). In cases of contact with the neural tube, the crest cell protrudes a few small pseudopodia to the basal surface of the neural tube cell and approaches to a distance of $4 \mathrm{~nm}$ (Fig. 3, 8), but in many cases the cell contacts not with the neural tube cell but with its basement membrane (Fig. 6). The contact between the neural crest cell and the basement membrane of the ectodermal cell is also seen

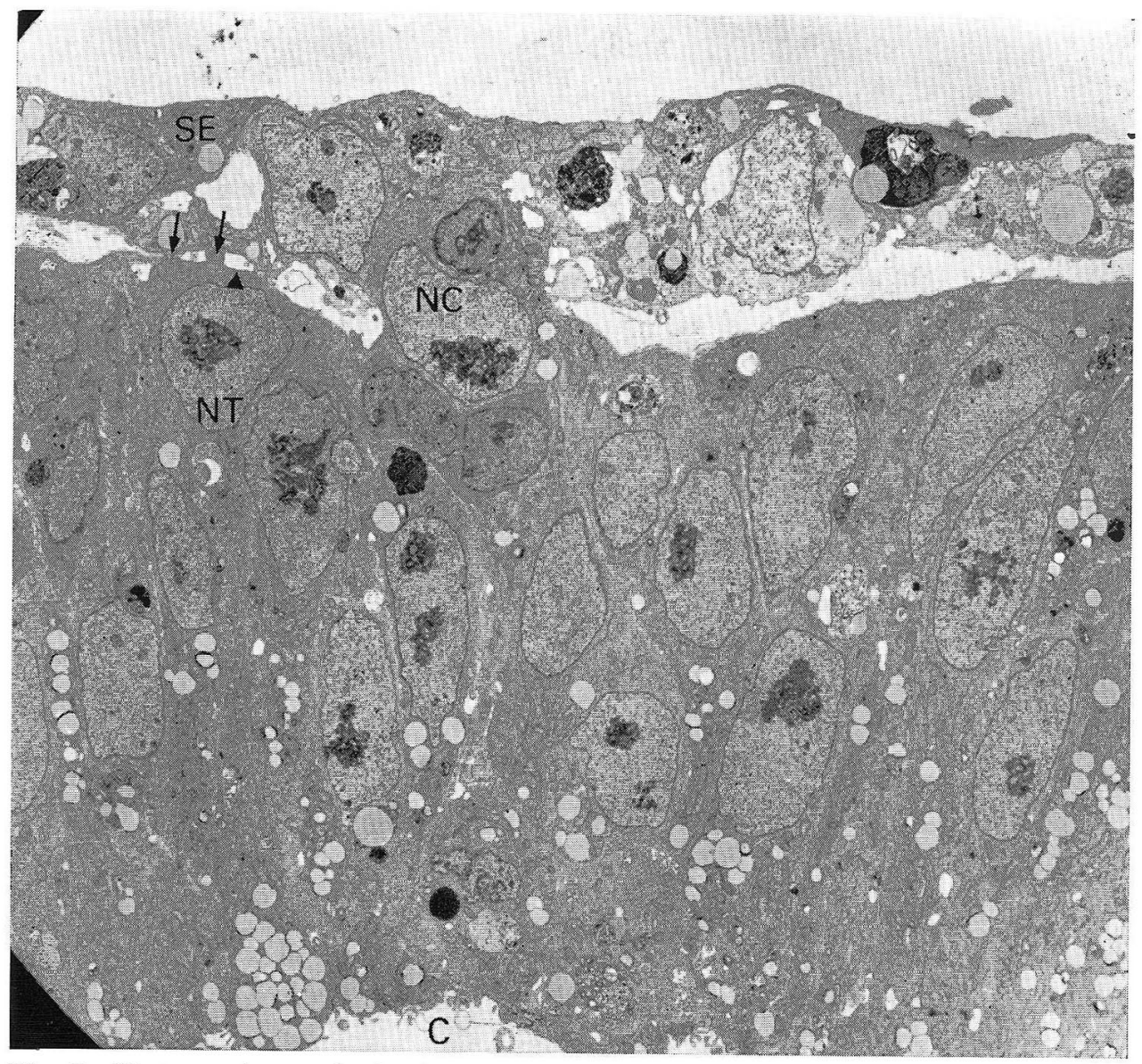

Fig. 7. Electron micrograph showing the mid-dorsal portion of a neural tube in the bantam embryo of 13 -somite stage. It is rather rare at this stage that the crest cell $(N C)$ is still seen in the area close to its source. Basement membranes are seen on the confronting surfaces of the ectodermal cell group and neural tube cell group. The contacts between pseudopodia of the crest cell and the neural tube cell (NT) are also observable (arrows). At the lowest part of the micrograph the neurocoel $(C)$ is observable. The portion indicated by an arrow-head is magnified in Figure $8 . \times 2,400$ 


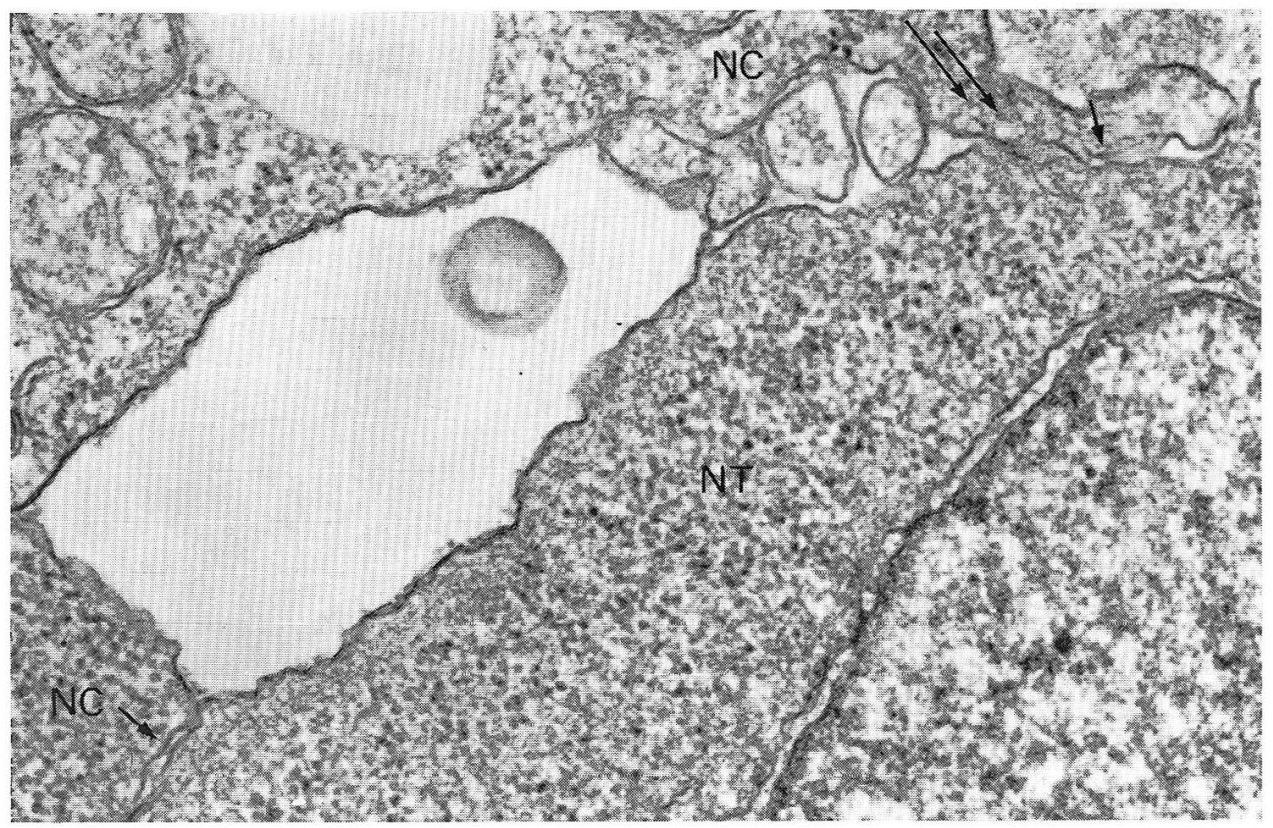

Fig. 8. Electron micrograph of higher magnification showing the portion indicated by the arrowhead in Figure 7. The double arrows show a pseudopodium of the crest cell. Arrows point to contacting regions between crest cells $(N C)$ and the neural tube cell $(N T)$. The distance of intercellular space at the region which is shown by an arrow is about $4 \mathrm{~nm}$. $\times 50,000$

It is difficult to identify the complete structure of the unit membrane at the contacting portion unless the membrane of the contacting cells was cut perpendicularly. Contact of the neural crest cell to the extracellular fibrillar structure is also seen (Fig. 3). The neural crest cell in these stages has a distinct elliptical nucleus which has an electron dense nucleolus. In the cytoplasm, numerous free ribosomes, a few vesicles, some endoplasmic reticulums and mitochondria are seen. However, no clear microfilament or microtubule is observable.

\section{DISCUSSION}

From observation of the initial migration of the neural crest cell in the midbrain of a bantam embryo, it was obvious that the migrating crest cell frequently keeps in contact with the superficial ectoderm and/or the neural tube by means of its pseudopodia or minute processes. It has been indicated that migrating neural crest cells interact closely with surrounding tissues in their pathways (WESTON, 1970, 1972; Johnston and Listgarten, 1972; Noden, 1975). Furthermore, by in vitro experiments of cell adhesion to the substrate such as the adhesion of embryonic fibroblasts to glass or plastics, it was made clear that cells adhere to the substrate by protruding processes (CurTis, 1964; TAKeICHI and OKADA, 1972). Lesseps (1963) observed in embryonic heart cells and pigmented retinal cells that cell contact was actually 


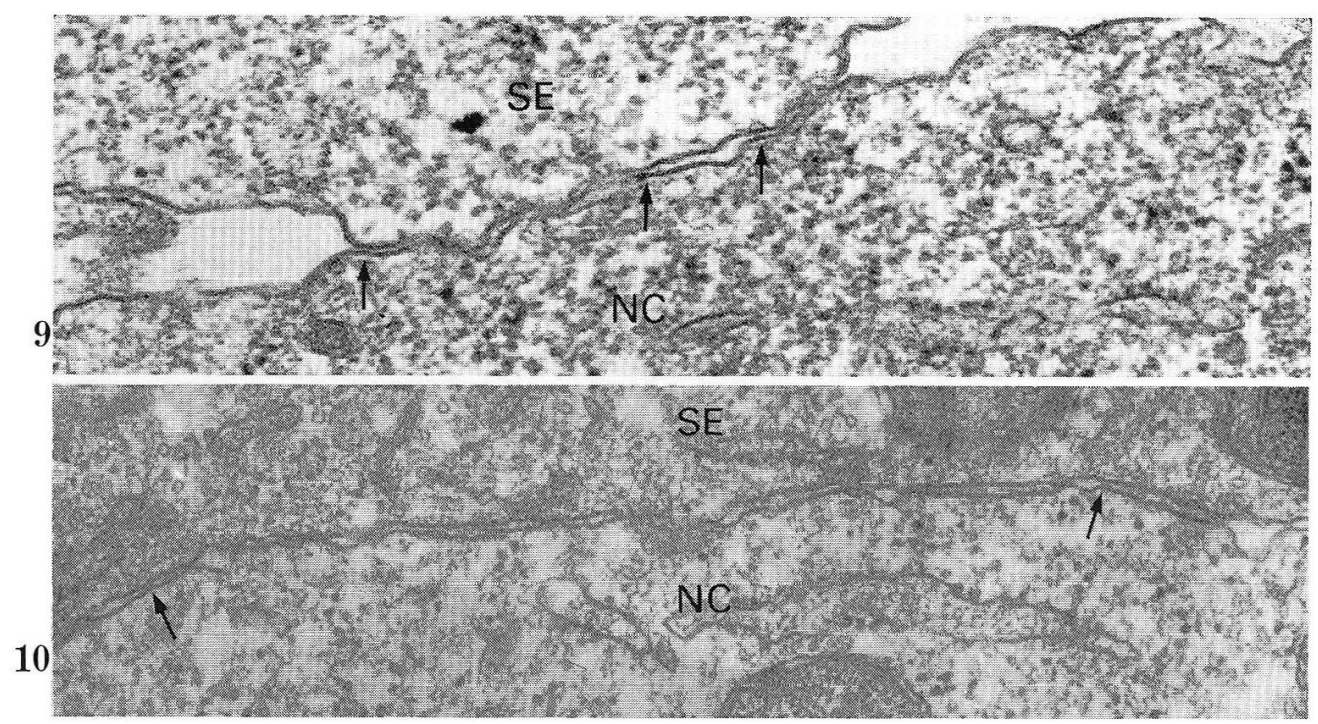

Fig. 9 and 10. These electron micrographs show higher magnification of the contacting regions between migrating crest cells $(N C)$ and superficial ectodermal cells $(S E)$. Unit membranes are clearly seen (arrows).

Fig. 9. Contacting regions between the neural crest cell and the ectodermal cell in the 9-somite stage. Arrows indicate the apposed membranes of the contact. The distance of intercellular space is about $3 \mathrm{~nm} . \quad \times 54,000$

Fig. 10. Contacting regions between the neural crest cell and the ectodermal cell in the 12 -somite stage. Arrows show contacting regions where the distance of intercellular space is narrower than $3 \mathrm{~nm} . \quad \times 43,000$

initiated at the crests of their undulating surfaces. OKADA (1975) proposed that cells always intend to approach each other or to approach the substrate more closely, projecting pseudopodia. Good (1972) also concluded in his theoretical study that the projection of pseudopodia is necessary to form molecular contact which is needed for phagocytosis or for the strong adhesion of blood cells to glass. Therefore, the projection of small processes seems to be an essential behavior for crest cells to approach more closely to ectodermal cells or neural tube cells.

The distance of contact between the crest cell and the superficial ectodermal cell or neural tube cell by minute processes or small pseudopodia was $3-4 \mathrm{~nm}$. Although it was impossible in the present study to confirm the interaction of contacting cells, this contacting area of close distance is thought to be the site of low resistance to ion flow in embryonic tissue as indicated by SHeridan (1966) and Trelstad et al. (1967). There is also an opinion that cells may interact through some unique transitory junctions in the embryonic tissue (TRELSTAD et al., 1967; Spiegelman and BennetT, 1974). Plaque contact (EBendal, 1977) or special junctions as in adult tissues was not observable. Lentonen et al. (1975) suggested that cell contact is necessary for cell interaction, from their experiments on the correlation between interacting metanephric mesenchyme and the spinal cord through Millipore filters of various pore sizes in mice. Spiegelman and Bennetr (1974) believed that contact and interaction between cells is doubtlessly a prerequisite for cell movement, as well 
as a likely condition for normal differentiation. Weston (1970, 1972) and NoDEN (1975) indicated that the precise patterns of migration of chick neural crest cells are largely directed by environmental influences. Weston $(1963,1970,1972)$ also indicated that prospective pigment cells making up the dorsolateral stream associate closely with the superficial ectoderm and enter its germinative layer. Therefore, the contact of neural crest cells having been observed here seems to be an important process for them to reach their target areas correctly.

In the cytoplasm of the crest cell it was impossible to observe the microfilaments. If the existence of the microfilaments were confirmed in pseudopodia of migrating neural crest cells, it would strongly support the idea that the crest cells intend to make contact with these cells actively. It is known that microfilaments are observed in many kinds of actively mobile cells and evidence to support the fact that cell movement is caused by microfilaments seems to be increasing (SPOONER et al., 1971, 1973). Crest cells which exhibit pseudopodia might be considered to be active in making contact (EBENDAL, 1977). There seem to exist two possibilities to explain the non-existence of microfilaments in the pseudopodia of neural crest cells as has been suggested by IsHIKAwA (1977): (1) microfilaments which had existed in the crest cell were extracted in the fixation procedure or (2) some contractile protein other than the microfilaments is involved in the crest cell movement.

EBENDAL (1977) observed the presence of extracellular microfibrils in the pathway of neural crest cells and sclerotome cells at the leg bud level of chick embryos (Stage 16-Stage 20). He indicated that extensive cell movements take place in association with the extracellular matrix consisting of microfibrils. The contact between the neural crest cell and the poorly developed extracellular fibrillar structure was seen (Fig. 3). The contact between the neural crest cell and the basement membrane of the neural tube cell and also between the neural crest cell and the basement membrane of the ectodermal cell were observed. It is interesting when the latter observation is connected with the report of PRATT et al. (1975) that hyaluronate, which may prevent the process of differentiation and may create a substratum suitable for crest cell migration, is rich in the basement membrane of the ectoderm and the neural tube.

In the present study, the authors observed the ultrastructure and nature of the contacts between the migrating neural crest cells and the cells and structures of the environment. The meaning of these contacts cannot be presumed only by the present observation. However, when the results of the observation in the present study are related to the reports and presumptions of the previous workers, these contacts are supposed to be an important factor for the migration of these neural crest cells. The ultrastructural observation of these contacts having been performed in the present study will provide some clues for further experimental studies of neural crest cell differentiation and migration. 


\section{移動初期におけるチャボ胚神経堤細胞の接触に関する電子顕微鏡的研究}

高橋等と山鳥崇

チャボ胚を用いて 中脳領域ておける移動初期の神経堤細胞（5体節期から15体節期）を電 子顕微鏡で観察した。 この砵究で 神経堤細胞の移動は 7〜8体節期に起こり 14 体節期に 終ること，および この間に神経堤細胞は他の神経堤細胞とのみならず，表層の外胚葉性 細胞，および神経管の細胞とも接触することが認められた．接触の場合，ての細胞間距離 は 3〜 $4 \mathrm{~nm}$ であった。 また細胞間の接触のみでなく, 神経堤細胞と神経管の細胞や 表層 の外肧葉細胞の基底膜との接触, および神経堤細胞と細胞閒の線維様の物質との接触など も認められた。この様な接触は，この時期の神経堤細胞とその周辺にある細胞，および細 胞間物質との間に，移動のための一時的な相互作用の存在する可能性を示している.

\section{REFERENCES}

Curtis, A. S. G.: The mechanism of adhesion of cells to glass. A study by interference reflection microscopy. J. Cell Biol. 20: 199-215 (1964).

Ebendal, T.: Extracellular matrix fibrils and cell contacts in the chick embryo. Possible roles in orientation of cell migration and axon extension. Cell Tiss. Res. 175: 439-458 (1977).

Good, R. J.: Theory of the adhesion of cells and the spontaneous sorting-out of mixed cell aggregates. J. theor. Biol. 37: 413-434 (1972).

Hamburger, V. and H. L. Hamilton : A series of normal stages in the development of the chick embryo. J. Morphol. 88: 49-92 (1951).

Ishikawa, H.: Cell motility. (In Japanese). Taisha 14: 1937-1945 (1977).

Johnston, M. C. and M. A. Listgarten : Observations on the migration, interaction, and early differentiation of orofacial tissues. In: (ed. by) H. C. Slavkin and L. A. Bavetta: Developmental aspects of oral biology. Academic Press, New York-London, 1972 (p. 53-80).

Kellenberger, E., A. Ryter and J. Séchaud: Electron microscope study of DNA-contacting plasms. II. Vegetative and mature phage DNA as compared with normal bacterial nucleoids in different physiological states. J. biophys. biochem. Cytol. 4: 671-678 (1958).

Lehtonen, E., J. Wartiovaara, S. Nording and L. Saxén: Demonstration of cytoplasmic processes in Millipore filters permitting kidney tubule induction. J. Embryol. exp. Morphol. 33: 187-203 (1975).

Lesseps, R. J.: Cell surface projections: their role in the aggregation of embryonic chick cells as revealed by electron microscopy. J. exp. Zool. 153: 171-182 (1963).

Luft, J. H.: Improvements in epoxy resin embedding methods. J. biophys. biochem. Cytol. 9: 409-414 (1961).

Millonig, G.: Further observations on a phosphate buffer for osmium solutions in fixation. In: (ed. by) S. S. Breese Jr.: Proc. 5th Int. Congr. for Electron Microscopy. Academic Press, New York-London, 1962 (p. 8).

Noden, D. M.: An analysis of the migratory behavior of avian cephalic neural crest cells. Devel. Biol. 42: 106-130 (1975). 
Okada, T. S.: Cellular adhesiveness. (In Japanese). In: (ed. by) T. Isemura et al.: Gendai no Seibutsugaku/Saibo no Kozo to Kino. Iwanami Shoten, Tokyo, 1975 (p. 277-289).

Pratt, R. M., M. A. Larsen and M. C. Johnston : Migration of cranial neural crest cells in a cellfree hyaluronate-rich matrix. Devel. Biol. 44: 298-305 (1975).

Saito, T. and H. Keino: Acrolein as a fixative for enzyme cytochemistry. J. Histochem. Cytochem. 24: 1258-1269 (1976).

Sato, T.: A modified method for lead staining of thin sections. J. Electron Microsc. 16: 193 (1967).

Sheridan, J. D.: Electrophysiological study of special connections between cells in the early chick embryos. J. Cell Biol. 31: C1-C5 (1966).

Spiegelman, M. and D. Bennett : Fine structural study of cell migration in the early mesoderm of normal and mutant mouse embryos (T-locus: $\left.\mathrm{t}^{9} / \mathrm{t}^{9}\right)$. J. Embryol. exp. Morphol. 32: 723-738 (1974).

Spooner, B. S., K. M. Yamada and N. K. Wessells: Microfilaments and cell locomotion. J. Cell Biol. 49: 595-613 (1971).

Spooner, B. S., J. F. Ash, J. T. Wrenn, R. B. Frater and N. K. Wessells : Heavy meromyosin binding to microfilaments involved in cell and morphogenetic movements. Tiss. Cell 5: 3746 (1973).

Takeichi, M. and T. S. Okada: Roles of magnesium and calcium ions in cell-to-substrate adhesion. Exp. Cell Res. 74: 51-60 (1972).

Trelstad, R. L., E. D. Hay and J. P. Revel : Cell contact during early morphogenesis in the chick embryo. Devel. Biol. 16: 78-106 (1967).

Weston, J. A.: A radioautographic analysis of the migration and localization of trunk neural crest cells in the chick. Devel. Biol. 6: 279-310 (1963).

- The migration and differentiation of neural crest cells. Advanc. Morphogenes. 8: 41114 (1970).

- Cell interaction in neural crest development. In: (ed. by) L. Silvestri: Cell interactions. American Elsevier, New York, 1972 (p. 286-292).

高 橋 等

干036 弘前市在府町 5

弘前大学医学部

第一解剖学教室
Dr. Hitoshi TAKahashi

First Department of Anatomy

Hirosaki University School of Medicine

Zaifucho 5, Hirosaki, 036 Japan 